\title{
Holocene paleoprecipitation over the present-day Sahara desert: Implications for the future
}

\author{
I MMSH/LAPMO 5, fue du Châtea de I'Horloge, B.P.647, 13094 Aix-en-Provence cedex 2, France \\ 2 Institute of Geology, Acudem of Sciences, 100029 Beijing. China
}

The moderate Holocene global warming has induced a totally distinct climatic scenario over northern Africa. It is implied that the expected man-made warming will probably produce the same change in atmospheric circulation.

The Sahara desert presently covers more than 9 million $\mathrm{km}^{2}$ in northern Africa, between the Mediterranean zone and the transitional, sahelian, semi-arid area separating it from the humid Tropics. About $8,000.000 \mathrm{~km}^{2}$ receive less than $100 \mathrm{~mm}$ mean annual rainfall, since neither the winter polar depressions nor the summer monsoons currently reach the vast central lowlands. where (as in the hypercontinental Western Desert of Egypt and the Taoudenni Basin in Mali) the water-budger is sometimes close to nought, with less than $5 \mathrm{~mm}$ rainfall for a potential evaporation of 5 to $6 \mathrm{~m}$ (Dubief, 1963; Figure $1)$.

Except for five very snall brackish water outcrops in the Ubari sand sea of Libya (the salinity of which was measured at $187 \%$.). there is no surface water in this hyperarid core, although occasional modest underflows from the massifs are marked by scarce vegetal lines of Acacias and Graminae across the desert. Therefore, the large number of Holocene paleolikes and swamps that have been observed in this vast area is indeed striking, as shown by the paleomaps synthesizing the radiocarbon dated observations (Petit-Maire and Riser, 1988: Petit-Maire et al. 1993): since lakes in arid or semiarid low latitude regions have a delicately balanced hydrologic budget, they are precious indicators of climatic change. The recorded water spots were located in nearly all the impervious closed depressions liable to retain meteoric water, or in the interdune troughs where the local dune-field nappe outcrops when rainfall percolates through the sand, but also in all the areas related to the base-level of regional aquifers, including the groundwater nappes of rivers at the margins of the desert (Figure 2). The clayey depressions or flats at the foot of the large limestone plateaus are very often lined with heavy travertines testifying to past spring emergences; they often display lacustrine carbonate sediments, now strongly eroded (Figure 3 ).

Figure 4 shows the latitudinal distribution of the dated Holocene paleolacustrine or paludal sediments between $16^{\circ} \mathrm{N}$ and $34^{\circ} \mathrm{N}$ (Petit-Maire and Guo, 1996). A greater number of paleolakes are recorded in the southern Sahara than in the northern Sahara. which is due to the fact that numerous observations to the North, performed before the generalized isotopic dating. could not be considered. However, the frequent occur- rence of Holocene water bodies is as obvious as the one in the southern Sahara.

In contrast, the area between $24^{\circ} \mathrm{N}$ and $30^{\circ} \mathrm{N}$ has brought much scarcer data for surface water, despite regional research aiming to fill in the blanks. The few recorded deposits are mainly located either in the central massifs (or where wadis running off them, still feeding small underflows, end up in closed depressions), and along the Atlantic coast. Nowadays, this area still constitutes the hyperarid saharan core, extending along and above the Tropic of Cancer. since it is out of the range of Mediterranean winter rainfall. Atlantic cyclones and Guinean monsoons (Figure 1; de Noblet et al., 1996) One could think that the flat morphology of this zone, to the East as to the West. is not favourable to remanence of water bodies, occasional precipitation either intiltrating or evaporating immediately, the potential evaporation being $6 \mathrm{~m}$. However, some areals could be favorable even at these latitudes, for instance the Kreb-en Naga in southwestern Algeria, the northeastern part of Mauretania and some areas of the Egyptian western Desert: despite reasonable possibilities for existence of paleolakes, no evidence was found (pers. comm. J. Fabre. S. Kröpelin, J. Riser).

It thus appears that two distinct groups of rains fed the recorded water bodies: one originated from the South (paleomonsoons). one originated from the North-West. corresponding to polar depressions and Atlantic cyclones. The former widely outpaced the current range of the tropical depressions. the latter crossed the Alas barrier in northern Algeria, which is quite exceptional nowadays. It is well known. since more than a decade (Rossignol-Strick, 1980; Kutzbach. 1981: Rognon et al.. 1983: Kutzbach and Street-Perrott, 1985: Fairbridge. 1986: Kutzbach, 1987: Prell and Kutzbach. 1987:

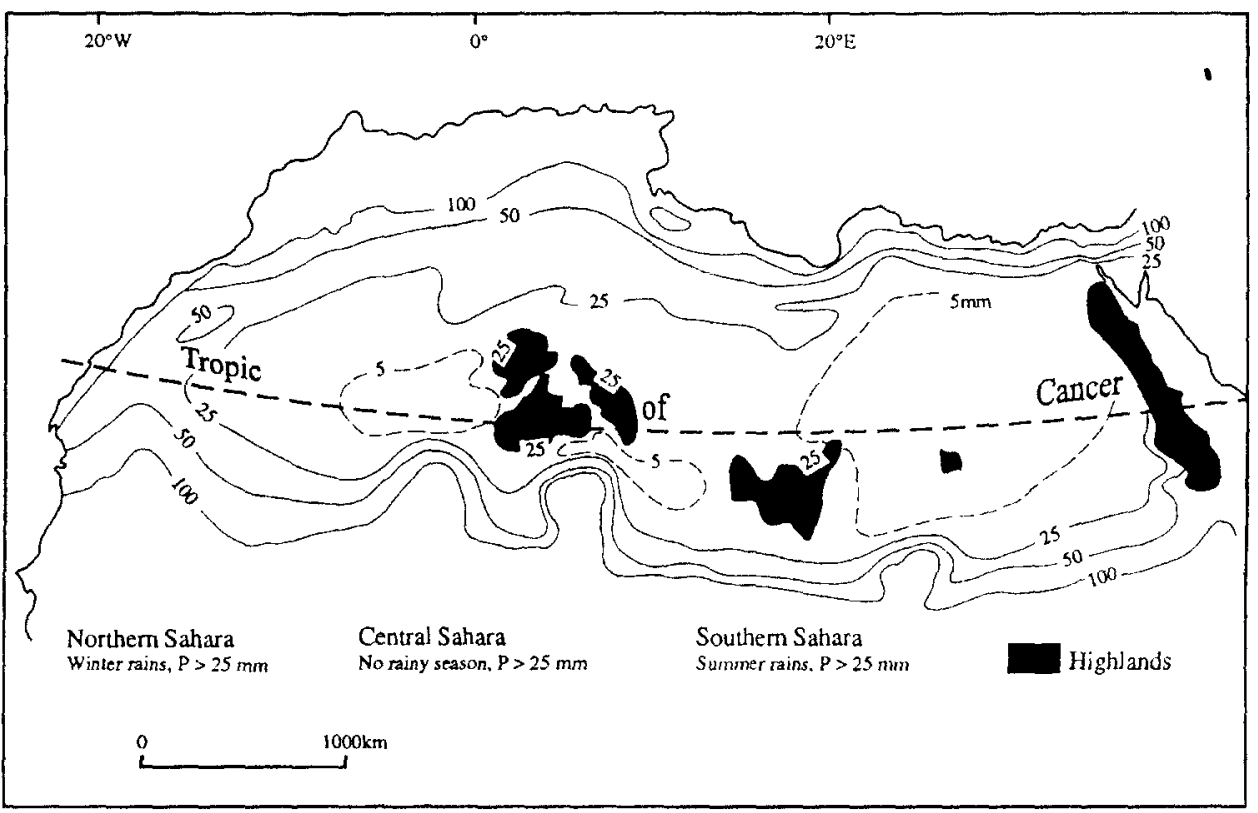

Figure 1 Present-day isohyets and origin of main rainfall in the Sahara desert (from Le Houérou, 1989). 
Petit-Mare. 1989: Yan and Petit-Maire, 1994: Petit-Maire et al.. 1995: Kutzbach. 1996) that past global warmings corresponded with an increase of the monsoons range and activity. Changes in rainfall from the North-West have not been as clearly demonstrated, although lakes in the northern Sahara have also been observed for long (Callot. 1984: Gasse et al. 1987: Petit-Maire et al., 1991) which testify to Mediterranean influence tar more southwards than nowadays.

Thus, the moderate Holocene global warming of about the same intensity as the one expected by models for our near future (Sadourny, 1994), has induced a totally distinct climatic scenario over northern Africa. Therefore, even if not induced by the same natural orbital causes, the expected man-made warming will probably produce the same changes in atmospheric circulation.

Will enhanced Greenhouse green the tropical deserts (Petit-Maire, 1990)? Since the demographic increase (world population doubling by 2038 ) is particularly high along the very margins of those arid areas, one may fear that the positive

Figure 2 During the Holocene warmer/wetter phase, the Niger River widely flooded the flat Azawad-Bouera region, North of Tombouctou (Petit-Maire and Riser, 1988). To the South, surface effluents from the river were perennial and ran in the interdune corridors from the cold/dry stage 2 arid phase. The Niger groundwater (Fontes et al., 1991) outcropped up to $300 \mathrm{~km}$ North in the many small depressions, in particular North of the 19th parallel. Around those fresh water spots, Neolithic sites and middens show Man could live there sedentary and fed on large fish (Petit-Maire and Gayet, 1984), water turtles, hippopotamus, crocodiles, large antelopes and even giraffes (Petit-Maire and Riser eds, 1983). 1. area supplied by the Niger floods, 2. area supplied by the floods and the phreatic nappe, 3. area suplied mostly by the phreatic nappe, 4, isolate lacustrine deposits, 5. ancient channels in the Pleistocene dune systems, 6. moving sand, 7. Pleistocene lacustrine limestone, 8. substratum outcrop.

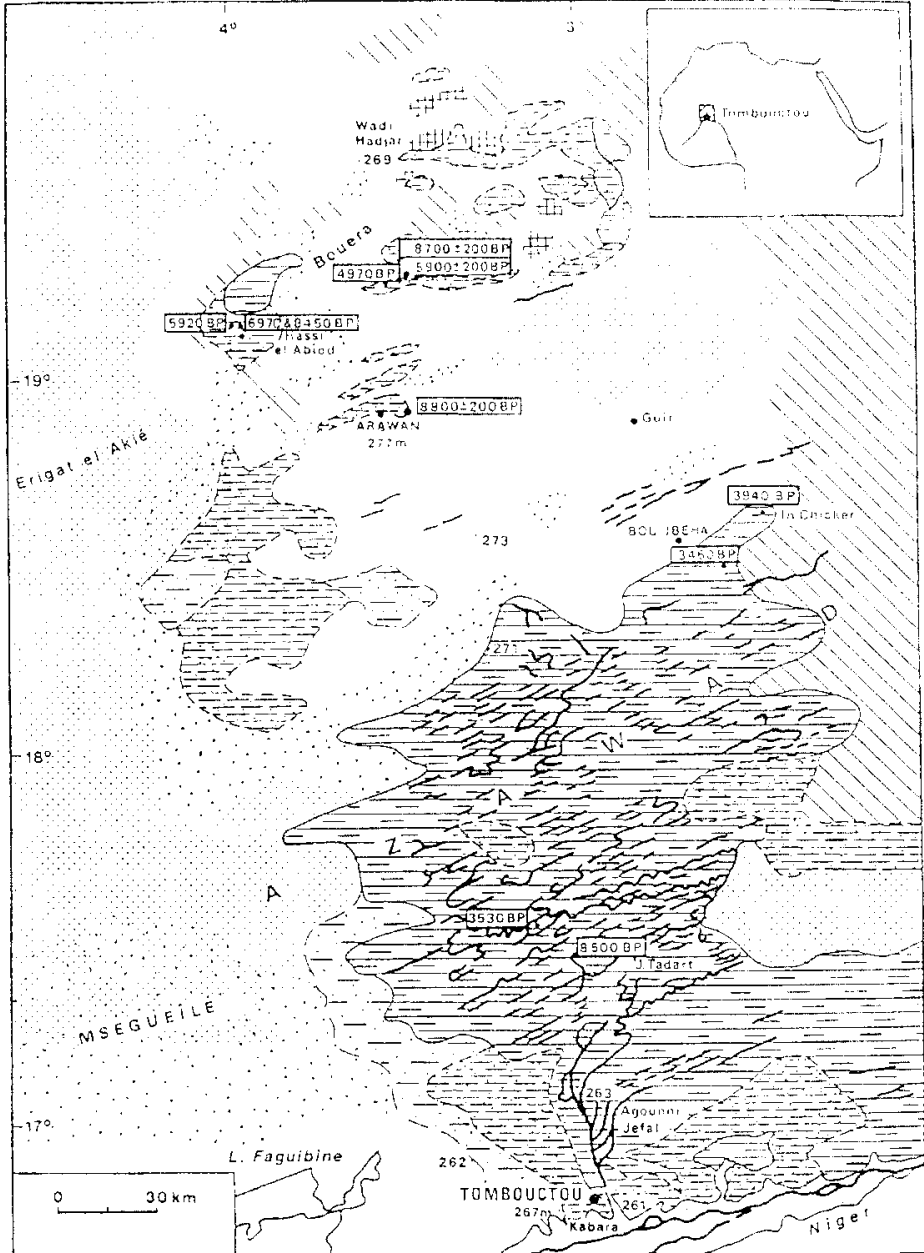

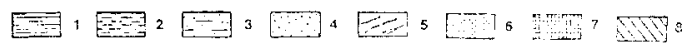

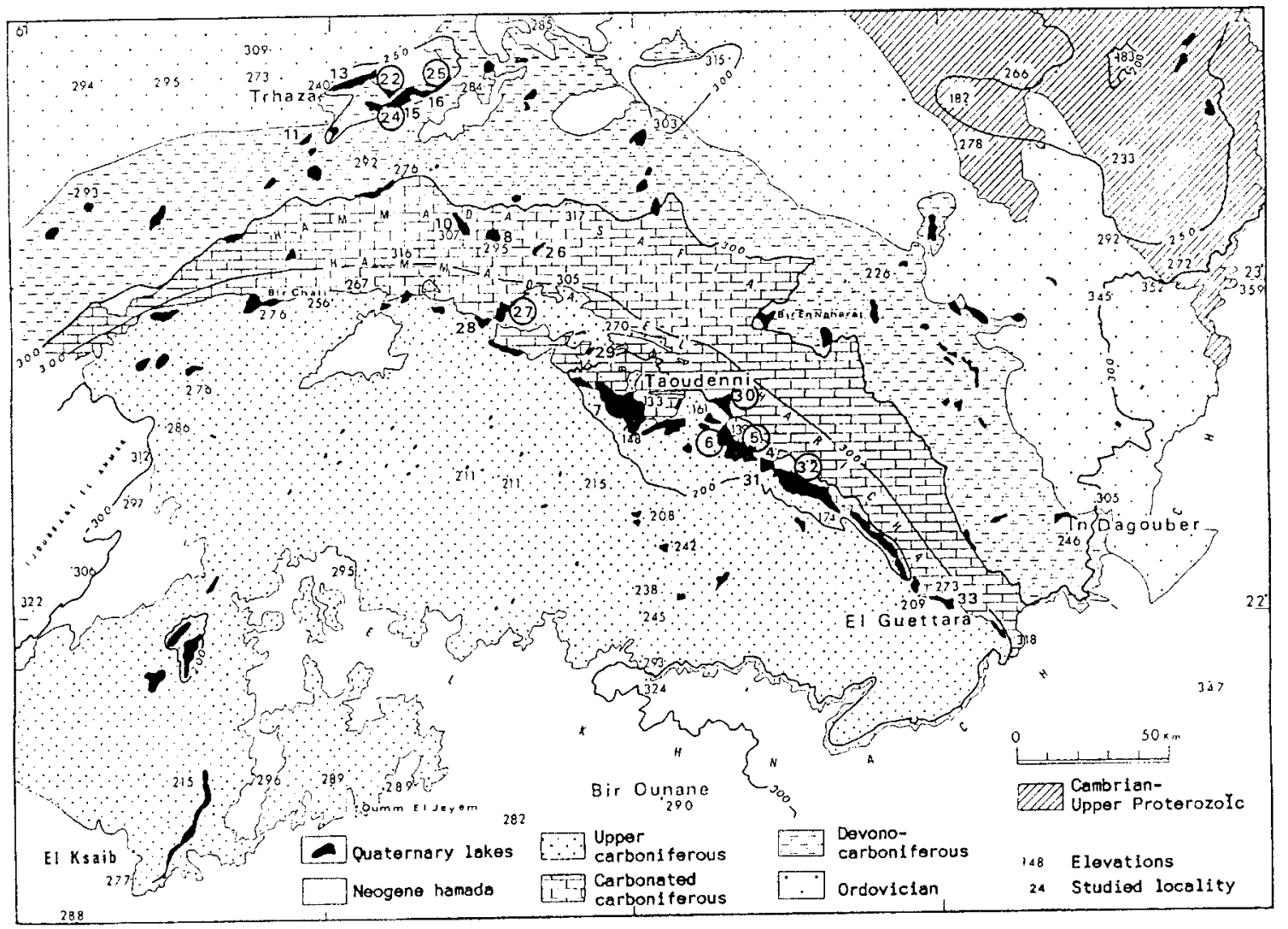

Figure 3 The flat bottom of the Carboniferous clayey "red country" was particularly favorable to the formation of paleolakes and swamps where dominated by the scarp of the limestone Haricha Plateau. All along the karstic formations, Holocene fresh water lakes have been observed (from Fabre and PetitMaire, 1988; PetitMaire ed., 1991). 


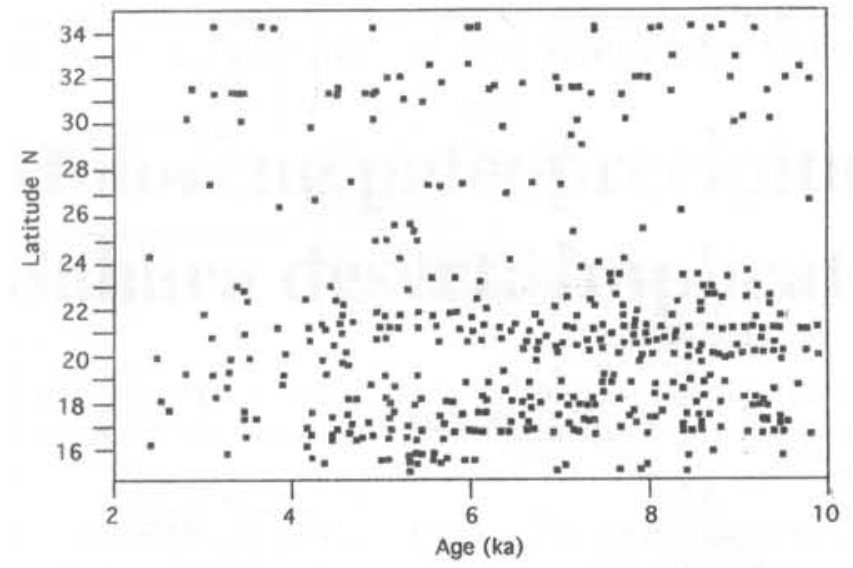

Figure 4 Distribution of Holocene paleolakes and swamps observed in the Sahara, according to latitude and age (from Petit-Maire and Guo, 1997).

effects of global warming upon the hydrological budget of these very regions will be counterbalanced or even suppressed by misuse of the increasing water resources, by trampling and cutting of the resilient vegetals and other human severe abuses of nature. The necessary "Wise Use of the Earth" pleaded for by IUGS's Past President, W. Fyfe (1992) should be especially applied to those regions that are to be first affected by probable near-future positive changes in atmospheric circulation.

\section{References}

Callot Y., 1984, Dépôts lacustres et palustres quaternaires de la bordure nord du Grand Erg Occidental, Algérie: C.R. Acad. Sci., Paris, 299, 11, 19:1347-1350.

Dubief J., 1963, Le climat du Sahara: Memoire Institut de Recherches Sahariennes, Alger. Tome I, 321p. Tome II, 275p.

Fabre J., Petit-Maire N., 1988, Holocene climatic evolution at $22^{\circ}-23^{\circ} \mathrm{N}$, Taoudenni (Mali): Paleogeography, Paleoclimatology, Paleoecology, 65:133-148.

Fairbridge R.H.,1986, Monsoons and Paleomonsoons: Episodes. 9, 3:143-149.

Fontes J.C., Callot Y., Plaziat J.C. Carbonel P., Dupeuble P., Kaczmarska I., 1985, Freshwater to marine-like environments from Holocene lakes in northern Sahara: Nature, 317:608-610.

Fontes J.C., Andrews J.N., Edmunds W.M.,Guerre A., Trair Y., 1991, Paleorecharge by the Niger River (Mali) deduced from groundwater geochemistry: Water Rseources Research, 27(2):199-214.

Fyfe W.S., 1992, Global change: anthropogenic forcing .The moving target: Terra Nova, 4: 284-287.

Gasse F., Fontes J.C., Plaziat J.C., Carbonel P., Kaczmarska I., De Deckker P., Soulié-Märsche I., Callot Y.. Dupeuble P., 1987, Biological remains geochemistry and stable isotopes for the reconstruction of environmental and hydrological changes in the Holocene lakes from Northern Sahara. Paleogeography, Paleoclimatology, Paleoecology, 60:1-46.

Kutzbach J.E., 1981, Monsoon climate of the Early Holocene: climate experiment with the Earth's orbital parameters for 9,000 yrs ago: Science. 214:59-61.

Kutzbach J.E., 1987, The changing pulse of the monsoon. in Fein J., Stephens P.(eds). Monsoons. Wiley: 247-258.

Kutzbach J.E.,Street-Perrott F.A., 1985, Milankovitch forcing of fluctuations in the level of tropical lakes from 18 to $0 \mathrm{Kyr}$ BP: Nature, 317: $130 \mathrm{~V} 134$.

Kutzbach J.E., Bonan G., Foley J., Harrison S.P., 1996, Vegetation and soil feedbacks on the response of the African monsoon to orbital forcing in the Early to Middle Holocene: Nature, 384:623-626.

Le Houerou H.N., 1989, Classification ecoclimatique des zones arides (s.1.) de I’ Afrique du Nord. Ecologia Mediterranea, 15, 314:95-144.

Noblet de, Braconot P., Joussaume S., Masson V., 1996, Sensitivity of simulated Asian and African summer monsoons to orbitally induced variations in inolation at 126, 115 and $6 \mathrm{k}$ BP: Climate Dynamics, 12:589-603.

Petit-Maire N., 1986, Paleoclimates in the Sahara of Mali: a multidisciplinary study: Episodes, 9,1:7-16.
Petit-Maire N., 1989, Interglacial environments in presently hyperarid Sahara: paleoclimatic implications. in Leinen M., Sarnthein M.(eds). Paleoclimatology and Paleometeorology: modern and past patterns of global atmospheric transport: Dordrecht, Kluwer: 637-661.

Petit-Maire N., 1990, Will Greenhouse green the Sahara?: Episodes, 13,2: 103-107.

Petit-Maire N (ed).,1991. Paléoenvironments du Sahara. Lacs Holocènes à Taoudenni (Mali): Editions du CNRS Marseille- Paris, 237 p.

Petit-Maire N., Burollet P., Ballais J.L., Fontugne M., Rosso J.C., Lazaar A., 1991. Paléoclimats holocènes du Sahara septentrional. Dépôts lacustres et terrasses alluviales en bordure du Grand Erg Oriental à l'extrême Sud de la Tunisie: C.R. Acad. Sci. Paris. Il.312:1661-1666.

Petit-Maire N., Gayet M., 1984, Hydrographie du Niger (Mali) à I'Holocène ancien: C.R. Acad. Sci., Paris, II.298:21-23.

Petit-Maire N., Guo Z.T., 1996, Mise en évidence de variations climatiques holocènes rapides en phase au Sahara et dans les déserts du Nord de la Chine: C.R. Acad, Sci., Paris, Il A, 322,10: 847-851.

Petit-Maire N., Guo Z.T., 1997, Holocene paleoprecipitation over the present-day Sahara desert. in Continental Signals of Paleomonsoon Dynamics in Africa: Inter-Hemispheric Perspectives. SIWA Workshop, Paleo-monsoons Project: 33.

Petit-Maire N.. Page N., Marchand J., 1993. The Sahara in the Holocene. Map 1/5 000 000: UNESCO-CGMW, Paris, France.

Petit-Maire N., Riser M J.(eds), 1983, Sahara ou Sahel?: CNRS, Marseille, $472 \mathrm{p}$.

Petit-Maire N., Riser J., 1987, Holocene paleohydrology of the Niger: Paleoecology of Africa, 18: 135-141.

Petit-Maire N., Riser J., 1988, Le Sahara à I' Holocène: Mali, Map 1/1 000 000. CGMW, Paris, France.

Petit-Maire N., Sanlaville P., Yan Z.W., 1995, Oscillations de la limite Nord $\mathrm{du}$ domaine des moussons africaine, indienne, et asiatique, au cours du dernier cycle climatique: Bull. Soc. Geol. France, 166, 2: 213-220.

Prell W.L., Kutzbach J.E., 1987, Monsoon variability over the past 150000 years: J. Geophysical Res., 92:8411-8425.

Riser J., Petit-Maire N.. 1986, Paleohydrographie du Bassin d'Araouane a I'Holocène: Rev. Geol. Dyn. et Geogr. Phys. 27,3-4: 205-212.

Rognon P., Levy A., Ballais J.L., Coude-Gaussen G., Riser J., 1983, Essais d'interprétation des coupes du Quaternaire récent de I'Oued El Akarit (Sud tunisien): Géol. Méditerranéenne, 10,2: 71-92.

Rossignol-Strick M., 1985, Mediterranean Quaternary sapropels, an immediate response of the African monsoon to variations of insulation: Paleogeography, Paleoclimatology, Paleoecology, 49: 237-263.

Sadourny R., 1994, L'influence du Soleil sur le climat: C R Acad. Sci. Paris, II. 319:1325-1342.

Yan Z.W., Petit-Maire N., 1994, The last 140 ka in the Afro-Asian climatic transitional zone: Paleogeography. Paleoclimatology. Paleoecology, 110: $217-233$.

Dr. N. Petit-Maire, a Director of Research at Centre National de la Recherche Scientifique, France, has been working in the world deserts, mainly the Sahara, specializing in field research of past environmental change across the most desolate hyperarid areas. She is one among the first international scientists who probed, and realized with a large team of specialists in earth and biological sciences, multidisciplinary studies of continental climatic variation.

Dr. Zhengtang Guo received his $P h$. $D$. degree in the University of Paris in 1990 and is now a Research Professor of the Institute of Geology, Chinese Academy of Sciences. His research interests include the Quaternary Geology, Paleoc-limatology and Paleopedology. He is now the Vicepresident of the INQUA Commission on Paleo-climate and a member of the PAGES Scientific Steering Committee.
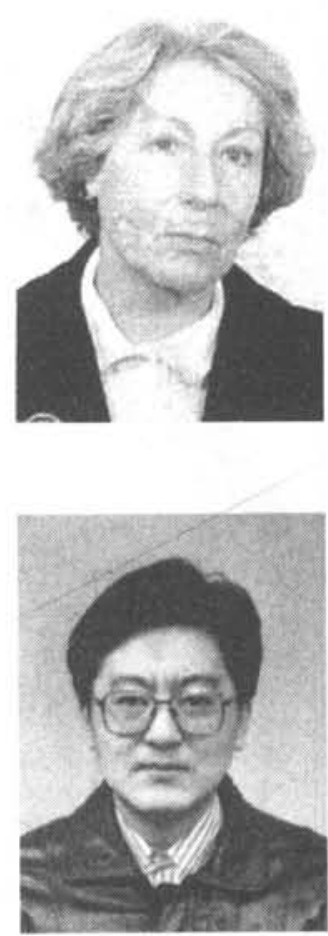